\title{
Microbial Production of Bioethanol from Gamma Irradiated Sugarcane Bagasse and Potato Peels
}

\author{
A.A.M. Abdelhafez ${ }^{\#}$, T.S. El-Tayeb ${ }^{\#}$, T.M. El-Mongi ${ }^{*}$ and \\ Marwa M. Moussa* \\ Department of Agricultural Microbiology, Faculty of Agriculture, \\ Ain Shams University and "Department of Irradiation \\ Microbiology, National Center for Radiation Research \& \\ Technology, Atomic Energy Authority, Cairo, Egypt.
}

\begin{abstract}
R ECENTLY, with growing crisis in fossil fuel and the .R. consequent of environmental pollution problems worldwide, bioethanol has become one of the most promising biofuels and many researchers have worked on improving the efficacy of the bioethanol production process. This work was concerned with producing bioethanol from low-cost raw agro-industrial feedstock (sugarcane bagasse and potato peels) and utilizing radiation technology to increase conversion rate of these materials to bioethanol. Both of sugarcane bagasse and potato peels were acid-hydrolyzed and resulted hydrolysates were fermented by either Zymomonas mobilis ATCC 29191, Saccharomyces cerevisiae ATCC 7754, or both organisms, cocultured (1:1). The effect of gamma irradiation on bioethanol production was studied by exposing the feedstock to different doses of gamma rays $(0,25,5075 \mathrm{kGy})$. Effect on combining gamma irradiation with acid treatment of feedstock on bioethanol production was also investigated. From sugarcane bagasse, the highest achieved final bioethanol concentration $\left(15.4 \mathrm{gL}^{-1}\right)$ was obtained from the combined pretreatment by irradiation with $75 \mathrm{kGy}$ followed by hydrolysis with $2 \%(\mathrm{v} / \mathrm{v}) \mathrm{H}_{2} \mathrm{SO}_{4}$ at $120^{\circ} \mathrm{C}$ for $60 \mathrm{~min}$ and fermented with co-culture (1:1) of Z. mobilis ATCC 29191 and Sacch. cerevisiae ATCC 29191. On the other hand, from potato peels the highest bioethanol concentration $\left(12.1 \mathrm{~g} \mathrm{~L}^{-1}\right)$ was obtained from combined pretreatment by irradiation with $75 \mathrm{kGy}$ and hydrolyzed by $6 \%(\mathrm{v} / \mathrm{v})$ $\mathrm{H}_{2} \mathrm{SO}_{4}$ at $100^{\circ} \mathrm{C}$ for 60 min then fermented with co-culture (1:1).
\end{abstract}

Keywords: Saccharomyces cerevisiae ATCC 7754, Zymomonas mobilis ATCC 29191, Bioethanol, Feedstock, Gamma irradiation, Dilute acid hydrolysis.

The rising concern over depleting fossil fuel and greenhouse gas limits has resulted in a high level of interest in non-conventional fuel originating from biorenewable sources including sugars, starches and lignocellulosic materials. The importance of the bioethanol production has increased in the last few years, but cost of production is still interfering with the deployment of this new technology, where the cost of used raw materials (sugar and starch-containing materials) represents about $40-70 \%$ of the total production cost. Using less valuable materials, like lignocellulosic agricultural waste, could significantly reduce the production

\#Contact authors e-mails: aabdelhafez@yahoo.com and tarekeltayeb@yahoo.com, 
expense (Abo-State et al., 2013). The lignocelluloses are mainly composed of cellulose, hemicellulose, and lignin. Cellulose chains interact with hemicellulose and lignin forming a lignin-carbohydrate complex, so that they must be pretreated and hydrolyzed to produce sugars for bioethanol fermentation (Ferdian et al., 2012). Because of its lower ash content (1.9\%), sugarcane bagasse offers numerous advantages compared with other agro-based residues such as paddy straw (16\%), rice straw (14.5\%) and wheat straw (9.2\%) (Cardona et al., 2010). Potato peel waste (PPW), also, contains sufficient quantities of starch, cellulose, hemicellulose, lignin and fermentable sugars to warrant use as an ethanol feedstock. Starch is a high yield feedstock for ethanol production, but its hydrolysis is required to produce ethanol by fermentation (Arapoglou et al., 2010). Pretreatment is an essential step for practical cellulose conversion processes that is required to modify the structure of cellulosic biomass to make cellulose more accessible to convert the carbohydrate polymers into fermentable sugars (Ribeiro et al., 2013). Recently, use of irradiation for degradation of various lignocellulosic materials, such as sugarcane bagasse, chaff, sawdust, corn stalk and rice straw bunch, to increase sugar yield, has gained great attention. It was demonstrated that irradiation pretreatment can cause significant breakdown of the structure of lignocellulose and increase the rate of enzymatic hydrolysis (Wang et al., 2012). Ribeiro et al. (2013) reported positive effect of absorbed doses of gamma irradiation, lower than $150 \mathrm{kGy}$, on the cleavage of polysaccharides from sugarcane bagasse. High-energy radiation causes a decrease in the degree of polymerization and an increase in the carbonyl content of cellulose due to the chain scission reaction within the cellulose molecules.

The current work aimed to study the effect of different doses of gamma irradiation on the cleavage of polysaccharides from sugarcane bagasse and potato peels with or without combination of dilute acid hydrolysis and the effect of these treatments on bioethanol production compared with dilute acid hydrolysis. Production of bioethanol by fermentation was carried out using Zymomonas mobilis ATCC 29191 and/or Saccharomyces cerevisiae ATCC 7754.

\section{Materials and Methods}

\section{Materials}

Microorganisms for bioethanol production

Saccharomyces cerevisiae ATCC 7754 and Zymomonas mobilis ATCC 29191 were obtained from The Microbiological Resources Center (Cairo MIRCEN), Faculty of Agriculture, Ain Shams University, Cairo, Egypt.

\section{Agro-industrial feedstock}

Sugarcane bagasse was obtained from sugar cane juice shop and potato peels was obtained from local food restaurants, both located in Shibin Al-Qanatir, AlQalyubiya Governorate, Egypt. Both sugarcane bagasse and potato peels were sun-dried then milled using a laboratory hammer mill (Retsch GmbH \& Co. KG, Germany) to pass through $1 \mathrm{~mm}$ screen. These feedstocks were homogenized and oven-dried at $45^{\circ} \mathrm{C}$ prior to chemical analysis and pretreatment assays. The dried materials were stored in airtight containers at room temperature before use.

Egypt. J.Microbiol. 50 (2015) 


\section{Media used}

YM medium (Wickerham, 1946) was used for cultivation, maintenance and seed culture of Sacch. cerevisiae ATCC 7754 with the following ingredients $\left(\mathrm{gL}^{-1}\right)$ : Yeast extract 3; malt extract 3; glucose 10; peptone 5; agar 15; pH $6.0 \pm 0.2$. ATCC medium 948 (Swings \& Deley, 1977) was used for cultivation, maintenance and seed culture of $Z$. mobilis ATCC 29191 with the following ingredients $\left(\mathrm{gL}^{-1}\right)$ : Glucose 20; yeast extract 5; agar 15; pH $6.5 \pm 0.2$.

\section{Methods}

Analysis of agro-industrial feedstock

Determination of moisture percentage: Five grams of each feedstock were dried in oven at $45^{\circ} \mathrm{C}$ overnight and left to cool in a desiccator and weighed until reach a constant weight. Moisture content of each sample was calculated (George et al., 2011).

Determination of total sugars: Total sugars were determined after hydrolysis treatments of sugarcane bagasse and potato peels. Total sugars were extracted according to the method reported by Pak \& Simon (2004) and the supernatants were used for sugar analysis. Total sugars analysis was determined by the Phenol-sulfuric acid method (Dubois et al., 1956 and Pak \& Simon, 2004).

Carbon and nitrogen content of feedstock: Carbon content of sugarcane bagasse and potato peels were determined according to Tiessen \& Moir (1993). Nitrogen content of feedstock was determined according to Stuart, (1936).

\section{Feedstock processing}

Bioethanol production from feedstock consisted of two main stages, first: Feedstock pretreatment and second: Bioethanol production. Feedstock pretreatment was performed by either dilute acid hydrolysis or gamma irradiation or the combination of both pretreatments. Bioethanol production was performed using neutralized (to $\mathrm{pH}$ 5.8) pretreated feedstock, on which Sacch. cerevisiae ATCC 7754 and Z. mobilis ATCC 29191 were inoculated to ferment released sugars into alcohol.

\section{Irradiation of feedstock}

Effect of gamma irradiation on bioethanol production was investigated by exposing feedstock to gamma " $\gamma$ " radiation (using Indian cobalt-60 gamma cell at the National Center for Radiation Research and Technology, Egyptian Atomic Energy Authority "EAEA", Cairo, Egypt). Irradiation of feedstock was examined to facilitate sugar release from feedstock, thus improving bioethanol production. Irradiation of feedstock was performed in a batch process and the delivered irradiation absorbed doses were 25, 50 and $75 \mathrm{kGy}$ (kiloGray); where Gray is a measurement unit of absorbed dose of gamma radiation, and exposure for $1 \mathrm{~min}=43.8$ Gray) (Thornley, 1963). Single and combined effect of irradiation and dilute acid treatments was studied by treating irradiated feedstock with $2 \%$ and $6 \%(\mathrm{v} / \mathrm{v})$ sulphuric acid $(98 \%)$ at $120^{\circ} \mathrm{C}$ for 30 or $60 \mathrm{~min}$. Sterilized flasks containing treated feedstock were inoculated with $5 \mathrm{ml}$ of $48 \mathrm{~h}$ old seed culture of tested microorganisms. Bioethanol production and extraction 
were done as described below. Flasks containing treated uninoculated or inoculated untreated feedstock were used as controls. Untreated feedstock was without acid hydrolysis or irradiation, contained $95 \mathrm{ml}$ distilled water.

Dilute acid hydrolysis

To determine the effect of acid concentration, retention time and hydrolysis temperature, 5 grams of feedstock were added to $250 \mathrm{ml}$ Erlenmeyer flask containing $95 \mathrm{ml}$ of $2 \%$ or $6 \%(\mathrm{v} / \mathrm{v})$ of sulphuric acid $(98 \%)$ or $95 \mathrm{ml}$ of tap water (the control treatment), $6.7 \pm 0.2$ (using $\mathrm{pH}$ meter EPH211-Hanna Instruments Inc),. Hydrolysis was run at either 100 or $120^{\circ} \mathrm{C}$ and the reaction time was 30 or 60 min (Pattana et al., 2010). The pretreated feedstock was left to cool then filtered to remove the solid fraction and the sugar-rich liquid filtrate was neutralized, as follows: the $\mathrm{pH}$ of the separated hydrolyzate was adjusted from around 0.001 to 5.8 in two steps, first by $\mathrm{NaOH}$ pellets to $\mathrm{pH}=3$ and second by Ammonia solution $(33 \%)$ to $\mathrm{pH}=5.8$.

\section{Bioethanol fermentation}

Before sterilization, neutralized hydrolyzate was supplemented with the following nutrients $\left(\mathrm{g} \mathrm{L}^{-1}\right): \mathrm{KH}_{2} \mathrm{PO}_{4} 2, \mathrm{MgSO}_{4} .7 \mathrm{H}_{2} \mathrm{O} 1$ and $\left(\mathrm{NH}_{4}\right)_{2} \mathrm{SO}_{4} 1$ (Davis et al., 2006) for Z. mobilis ATCC 29191 and yeast extract 3, peptone 3.5, $\mathrm{KH}_{2} \mathrm{PO}_{4} 2, \mathrm{MgSO}_{4} .7 \mathrm{H}_{2} \mathrm{O} 1$ and $\left(\mathrm{NH}_{2}\right)_{2} \mathrm{SO}_{4} 1$ for Sacch. cerevisiae ATCC 7754 (Arapoglou et al., 2010). After that, hydrolyzate was autoclaved at $121{ }^{\circ} \mathrm{C}$ for 20 min and used for bioethanol production. Flasks containing $95 \mathrm{ml}$ of neutralized sterilized feedstock (non-hydrolyzed, dilute acid-hydrolyzed, gamma-irradiated or combined treated with gamma irradiation and dilute acid) were inoculated with $5 \mathrm{ml}$ of $48 \mathrm{~h}$ old liquid seed cultures of Sacch. cerevisiae ATCC 7754, Z. mobilis ATCC 29191 or co-cultures of both organisms (at 1:1 ratio). Flasks were incubated in anaerobic incubator (Labconco Manufacturing Corp., USA) at $30 \pm$ $2^{\circ} \mathrm{C}$ for 4 days. After incubation, bioethanol was extracted by transferring $100 \mathrm{ml}$ of the grown culture to a rotary evaporator (R206D 2L-SENCO) and the apparatus was run for $10-20 \mathrm{~min}$ at $78.5^{\circ} \mathrm{C}$. The distillate was used to determine bioethanol concentration as described later. Standard inoculum (seed culture) of each organism was prepared by inoculating test tubes containing $5 \mathrm{ml}$ broth media of YM (for Sacch. cerevisiae ATCC 7754 cultivation) or ATCC 948 medium (for Z. mobilis ATCC 29191 cultivation) with a full loop of tested culture and incubated at $30^{\circ} \mathrm{C}$ for $48 \mathrm{~h}$. All tests were performed in triplicates.

\section{Bioethanol determination}

Distillate obtained from rotary evaporator was used to determine bioethanol concentration colormetrically using potassium dichromate method (Crowell \& Ough, 1979).

Determination of viable cells count

Viable cells count of both organisms was carried out by plate count method (Talyour, 1962).

(Gamal et al. 1991). 
Bioethanol production parameters:

$$
\begin{aligned}
& \text { Conversion coefficient }(\%)=\frac{\text { Bioethanol concentration produced }\left(\mathrm{g} \mathrm{L}^{-1}\right)}{\text { Consumed sugars }\left(\mathrm{g} \mathrm{L}^{-1}\right)} \times 100 \\
& \text { Bioethanol yield }(\% \mathrm{w} / \mathrm{w})=\frac{\text { Bioethanol concentration produced }\left(\mathrm{g} \mathrm{L}^{-1}\right)}{\text { Initial sugars }\left(\mathrm{g} \mathrm{L}^{-1}\right)} \times 100
\end{aligned}
$$

Sugar utilizing efficiency $(\% \mathrm{w} / \mathrm{w})$ :

(Ramadan et al., 1985).

Sugar utilizing efficiency $(\% \mathrm{w} / \mathrm{w})=\frac{\text { Consumed sugars }\left(\mathrm{g} \mathrm{L}^{-1}\right)}{\text { Initial sugars }\left(\mathrm{g} \mathrm{L}^{-1}\right)} \times 100$

Statistical analysis

Data was analyzed by the method of SAS, (1996). Differences between means were compared using Duncan's Multiple Range Test according to Duncan, (1955).

\section{Results and Discussion}

Analysis of agro-industrial feedstock

For sugarcane bagasse and potato peels the moisture content was $16.7 \%$ $(\mathrm{w} / \mathrm{w})$ and $22.2 \%(\mathrm{w} / \mathrm{w})$, total carbon was $41 \%(\mathrm{w} / \mathrm{w})$ and $38 \%(\mathrm{w} / \mathrm{w})$, total nitrogen was $0.52 \%(\mathrm{w} / \mathrm{w})$ and $0.69 \%(\mathrm{w} / \mathrm{w})$ and $\mathrm{C} / \mathrm{N}$ ratio was 79 and 55, respectively.

\section{Effect of gamma irradiation on bioethanol production}

Throughout this work, the effect of gamma irradiation was conducted on cellulosic feedstock to enhance the bioethanol production process. Two locally available low-price agricultural wastes, sugarcane bagasse and potato peels, were used for bioethanol production by Saccharomyces cerevisiae ATCC 7754 and Zymomonas mobilis ATCC 29191 in batch culture process.

\section{Bioethanol production}

Bioethanol production was examined on neutralized acid hydrolyzed feedstock using a co-culture (1:1) of Sacch. cerevisiae ATCC 7754 and Z. mobilis ATCC 29191 (Table 1). The highest final bioethanol concentration, bioethanol yield and conversion coefficient were obtained by the cultivation on neutralized sugarcane bagasse hydrolyzed by $2 \%(\mathrm{v} / \mathrm{v}) \mathrm{H}_{2} \mathrm{SO}_{4}$ at $120^{\circ} \mathrm{C}$ for 60 min being $11.3 \mathrm{~g} \mathrm{~L}^{-1}, 47.7 \% \mathrm{w} / \mathrm{w}$ and $48.3 \% \mathrm{w} / \mathrm{w}$, respectively. This treatment also achieved the highest sugar utilization efficiency $(98.7 \% \mathrm{w} / \mathrm{w})$ and highest cells count $\left(10.8 \times 10^{5} \mathrm{CFU} \mathrm{ml}^{-1}\right)$. On the other hand, the highest final bioethanol concentration, bioethanol yield and conversion coefficient obtained from potato peels were from hydrolysis treatment by $6 \%(\mathrm{v} / \mathrm{v}) \mathrm{H}_{2} \mathrm{SO}_{4}$ at $100^{\circ} \mathrm{C}$ for $60 \mathrm{~min}$ being $10.7 \mathrm{~g} \mathrm{~L}^{-1}, 44.6 \% \mathrm{w} / \mathrm{w}$ and $46.9 \% \mathrm{w} / \mathrm{w}$, respectively. 


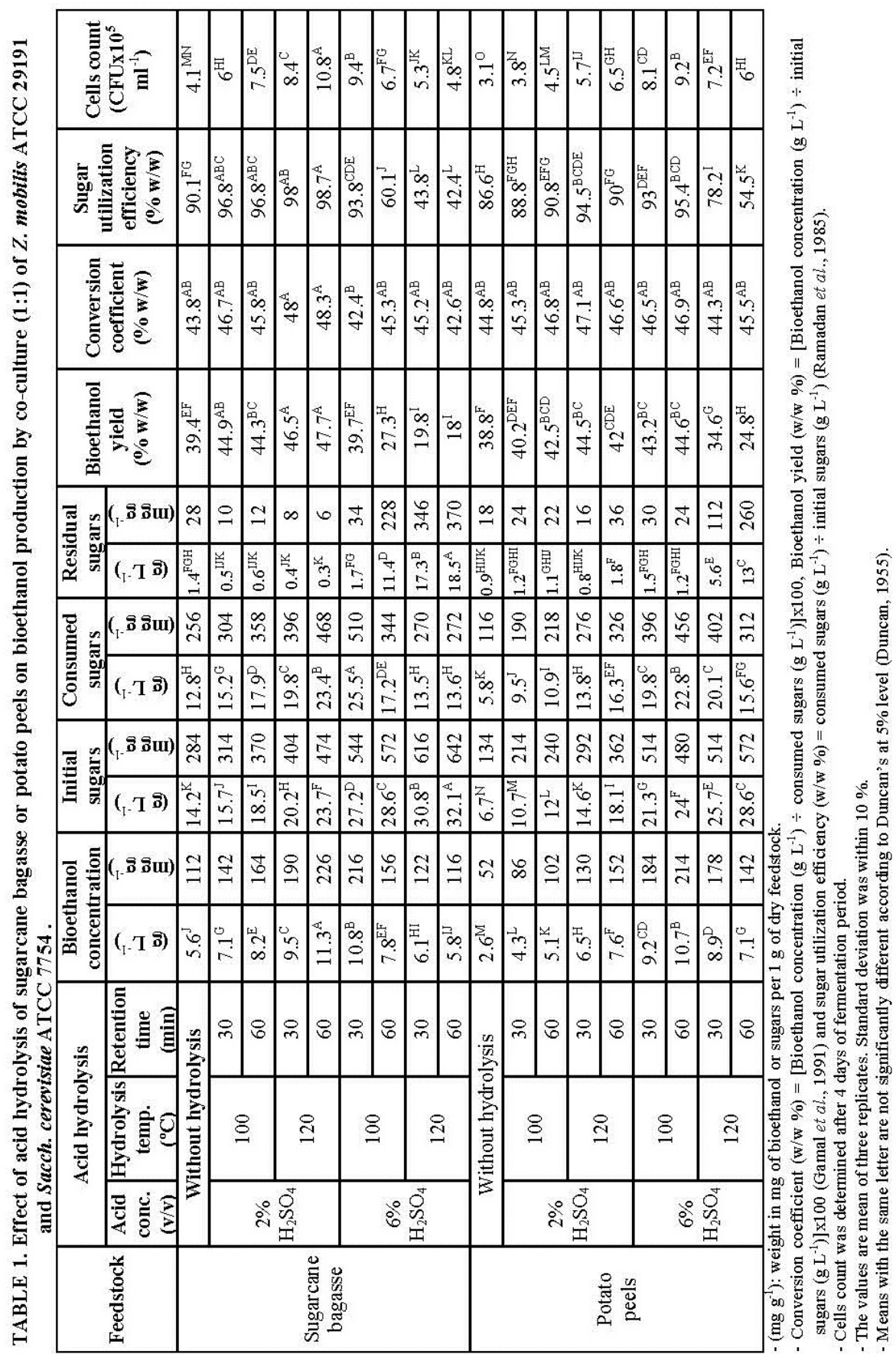

Egypt. J.Microbiol. 50 (2015) 
Our results were comparative to those of Oyeleke et al. (2012) who reported that using mixed culture of Sacch. cerevisiae and Z. mobilis produced maximum bioethanol yield of $26 \%$ from cassava peels and $12 \%$ from sweet potato peels and these results were attributed due to the combined activity of the two organisms to produce bioethanol. Their results also revealed that cassava peels produced higher bioethanol yield than sweet potato peels, which was due to the presence of more carbohydrate in cassava peels than in sweet potato peels. Another related study (Hashem \& Darwish, 2010) observed that maximum bioethanol yield $\left(5.5 \mathrm{~g} \mathrm{~L}^{-1}\right)$ was achieved by Sacch. cerevisiae y-1646 after $36 \mathrm{~h}$ in batch fermentation using dilute acid hydrolysis of potato residue by $1 \%(\mathrm{v} / \mathrm{v})$ $\mathrm{H}_{2} \mathrm{SO}_{4}$, which was efficient enough to hydrolyze all starch content of potato residue.

Effect of gamma irradiation of non-hydrolyzed feedstock on bioethanol production

Bioethanol production was examined on non-hydrolyzed irradiated sugarcane bagasse and potato peels (at $0,25,50$ and $75 \mathrm{kGy}$ ) using single or co-culture of $Z$. mobilis ATCC 29191 and Sacch. cerevisiae ATCC 7754. As shown in Table 2, a significant increase in final bioethanol concentration was recorded by the coculture cultivation on irradiated sugarcane bagasse compared to that obtained from non-irradiated sugarcane bagasse (Table 1). The highest final bioethanol concentration, bioethanol yield and conversion coefficient $\left(8.2 \mathrm{~g} \mathrm{~L}^{-1}, 43.2 \% \mathrm{w} / \mathrm{w}\right.$ and $46.3 \% \mathrm{w} / \mathrm{w}$, respectively) were obtained from sugarcane bagasse irradiated at the dose of $75 \mathrm{kGy}$ by co-culture cultivation. In this treatment, the highest cells count was recorded in the co-culture $\left(7.6 \times 10^{5} \mathrm{CFU} \mathrm{ml}{ }^{-1}\right)$. The same treatments were applied to potato peels, of which data Table 3 demonstrated that bioethanol concentration slightly increased by the co-culture cultivation on irradiated potato peels compared with that obtained from non-irradiated potato peels (Table 1). The highest final bioethanol concentration, bioethanol yield and conversion coefficient $\left(3.5 \mathrm{~g} \mathrm{~L}^{-1}, 36.5 \% \mathrm{w} / \mathrm{w}\right.$ and $43.8 \% \mathrm{w} / \mathrm{w}$, respectively) were obtained from potato peels irradiated at the dose of $75 \mathrm{kGy}$ inoculated with co-culture. In this treatment, the highest cell count was recorded in the co-culture $\left(4.7 \times 10^{5} \mathrm{CFU} \mathrm{ml}^{-1}\right)$. These results are in agreement with those of Qian et al. (2006), who demonstrated that using co-culture of Sacch. cerevisiae and recombinant Escherichia coli (carrying both $p d c$ and $a d h B$ genes derived from $Z$. mobilis) to ferment acid hydrolyzate of softwood bioethanol production achieved a high ethanol yield of $0.49 \mathrm{~g}$ ethanol/g sugars, corresponding to $96.1 \%$ of the maximum theoretical bioethanol yield after $24 \mathrm{~h}$. However, our results disagreed with those of Duarte et al. (2008), who found that irradiation of sugarcane bagasse with low doses (lower than $20 \mathrm{kGy}$ ) can cleave the external structure of sugarcane bagasse without destroying the cellulose or losing sugars.

Effect of combining dilute acid hydrolysis with gamma irradiation of feedstock on bioethanol production

As illustrated in Table 4, bioethanol production was conducted on sugarcane bagasse irradiated at doses of 25,50 and $75 \mathrm{kGy}$, followed by hydrolysis with 2 $\%$ (v/v) $\mathrm{H}_{2} \mathrm{SO}_{4}$ at $120^{\circ} \mathrm{C}$ for 30 or $60 \mathrm{~min}$ and fermented using single or coculture of Z. mobilis ATCC 29191 and Sacch. cerevisiae ATCC 7754. A significant increase in final bioethanol concentration was recorded by the coculture treatment compared with that obtained by the co-culture cultivated on

Egypt. J.Microbiol. 50 (2015) 
sugarcane bagasse treated only with dilute acid (Table 1). The highest final bioethanol concentration, bioethanol yield and sugar utilization efficiency were obtained from sugarcane bagasse irradiated at the dose of $75 \mathrm{kGy}$ followed by acid hydrolysis with $2 \%(\mathrm{v} / \mathrm{v}) \mathrm{H}_{2} \mathrm{SO}_{4}$ at $120^{\circ} \mathrm{C}$ for $60 \mathrm{~min}\left(15.6 \mathrm{~g} \mathrm{~L}^{-1}, 44.8 \%\right.$ $\mathrm{w} / \mathrm{w}$ and $93.7 \% \mathrm{w} / \mathrm{w}$, respectively). In this treatment, the highest cells count was recorded in the co-culture $\left(13.6 \times 10^{5} \mathrm{CFU} \mathrm{ml}^{-1}\right)$.

Similarly, bioethanol production was also examined on potato peels irradiated at doses of 25, 50 and $75 \mathrm{kGy}$, followed by hydrolysis with $6 \%(\mathrm{v} / \mathrm{v})$ $\mathrm{H}_{2} \mathrm{SO}_{4}$ at $100^{\circ} \mathrm{C}$ for 30 and $60 \mathrm{~min}$ and using single or co-culture of $\mathrm{Z}$. mobilis ATCC 29191 and Sacch. cerevisiae ATCC 7754 (Table 5). A significant increase in final bioethanol concentration was recorded comparing with that obtained by the co-culture cultivation on the acid hydrolyzed potato peels (Table 1). The highest final bioethanol concentration, bioethanol yield and sugar utilization efficiency were obtained from potato peels irradiated at the dose of 75 $\mathrm{kGy}$ followed by acid hydrolysis with $6 \%$ (v/v) $\mathrm{H}_{2} \mathrm{SO}_{4}$ at $120^{\circ} \mathrm{C}$ for $60 \mathrm{~min}$ (12.1 $\mathrm{g} \mathrm{L}^{-1}, 41.7 \% \mathrm{w} / \mathrm{w}$ and $87.6 \% \mathrm{w} / \mathrm{w}$, respectively). In this treatment, the highest cells count was observed by the co-culture $\left(11.8 \times 10^{5} \mathrm{CFU} \mathrm{ml}{ }^{-1}\right)$.

Generally, all combined treatments led to increasing the total sugars (initial sugars) of both sugarcane bagasse and potato peels compared with dilute acidhydrolyzed feedstock. In the case of sugarcane bagasse, the highest total sugars (34.8 $\mathrm{g} \mathrm{L}^{-1}, 696 \mathrm{mg} / \mathrm{g}$ sugarcane bagasse) was obtained by the combined treatment of feedstock composed of irradiation at $75 \mathrm{kGy}$ with hydrolysis by $2 \%$ (v/v) $\mathrm{H}_{2} \mathrm{SO}_{4}$ at $120^{\circ} \mathrm{C}$ for 60 min. Similarly, the highest total sugars $\left(31 \mathrm{~g} \mathrm{~L}^{-1}\right.$, $620 \mathrm{mg} / \mathrm{g}$ potato peels) was obtained by the combined treatment of feedstock composed of irradiation at $75 \mathrm{kGy}$ and hydrolysis by $6 \%(\mathrm{v} / \mathrm{v}) \mathrm{H}_{2} \mathrm{SO}_{4}$ at $100^{\circ} \mathrm{C}$ for $60 \mathrm{~min}$.

Finally, it can be recommended that the best method for bioethanol production from sugarcane bagasse is composed of co-culture cultivation of $Z$. mobilis ATCC 29191 and Sacch. cerevisiae ATCC 7754 (1:1) on feedstock irradiated at $75 \mathrm{kGy}$ followed by the dilute acid hydrolysis using $2 \%(\mathrm{v} / \mathrm{v})$ $\mathrm{H}_{2} \mathrm{SO}_{4}$ at $120^{\circ} \mathrm{C}$ for $60 \mathrm{~min}$. Similarly, the recommended method for bioethanol production from potato peels is composed of the same co-culture treatment on feedstock irradiated at $75 \mathrm{kGy}$ followed by the dilute acid hydrolysis using $6 \%$ (v/v) $\mathrm{H}_{2} \mathrm{SO}_{4}$ at $120^{\circ} \mathrm{C}$ for $60 \mathrm{~min}$. These results agreed with those obtained by Duarte et al. (2012) and Duarte et al. (2013), who found that the combination of dilute acid hydrolysis and irradiation pretreatment of sugarcane bagasse resulted in improving the bioethanol production. Ribeiro et al. (2013) also stated that the free radicals produced by interaction of high-energy radiation with polysaccharides resulted in decreasing the degree of polymerization and increasing the carbonyl content due to the chain cleavage in the cellulose and hemicelluloses molecules, in addition to the decrease in the formation of by-products such as furfural, hydroxymethyl-furfural and acetic acid, which affect the growth of fermentative microorganisms.

Egypt. J.Microbiol. 50 (2015) 


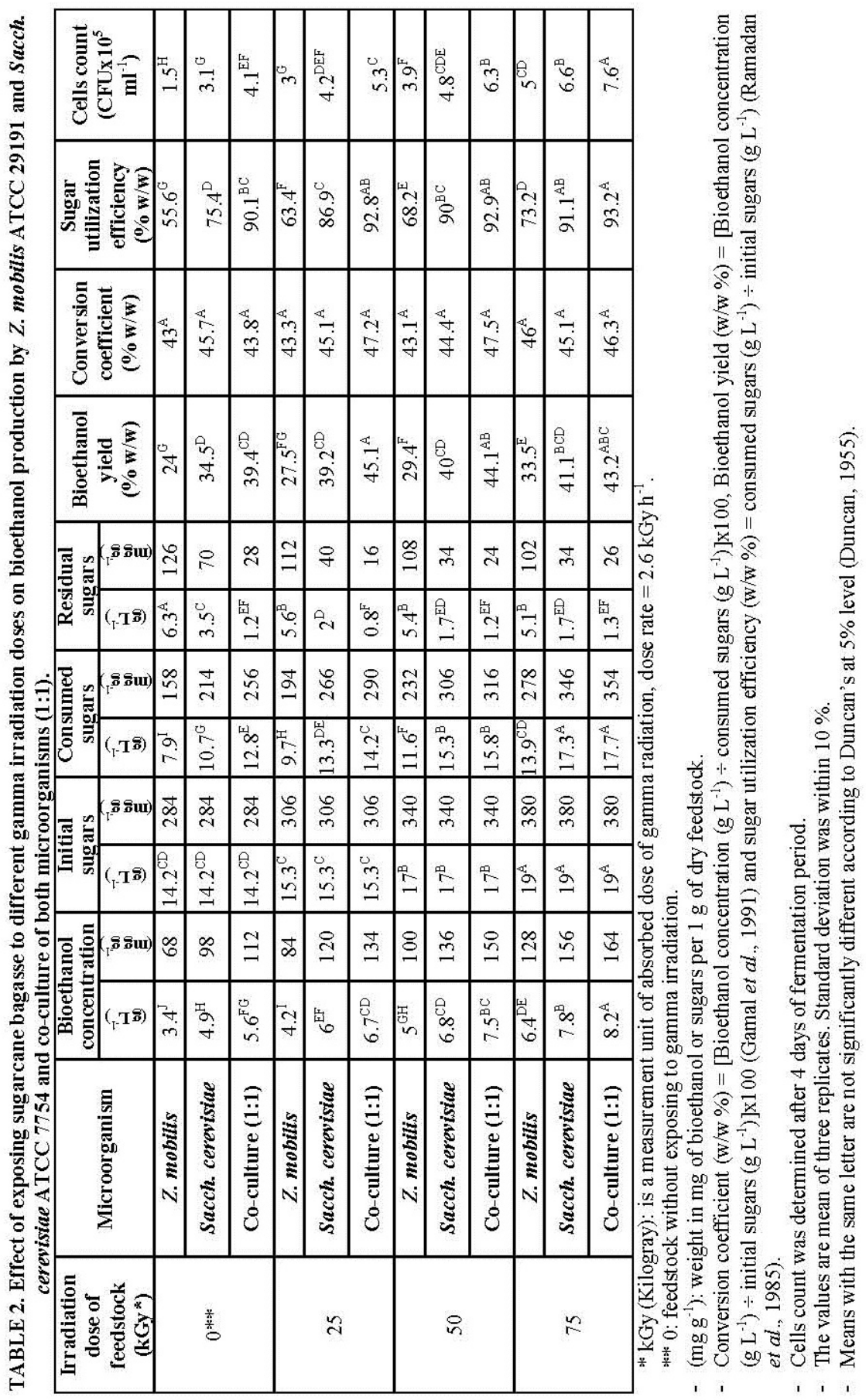

Egypt. J.Microbiol. 50 (2015) 


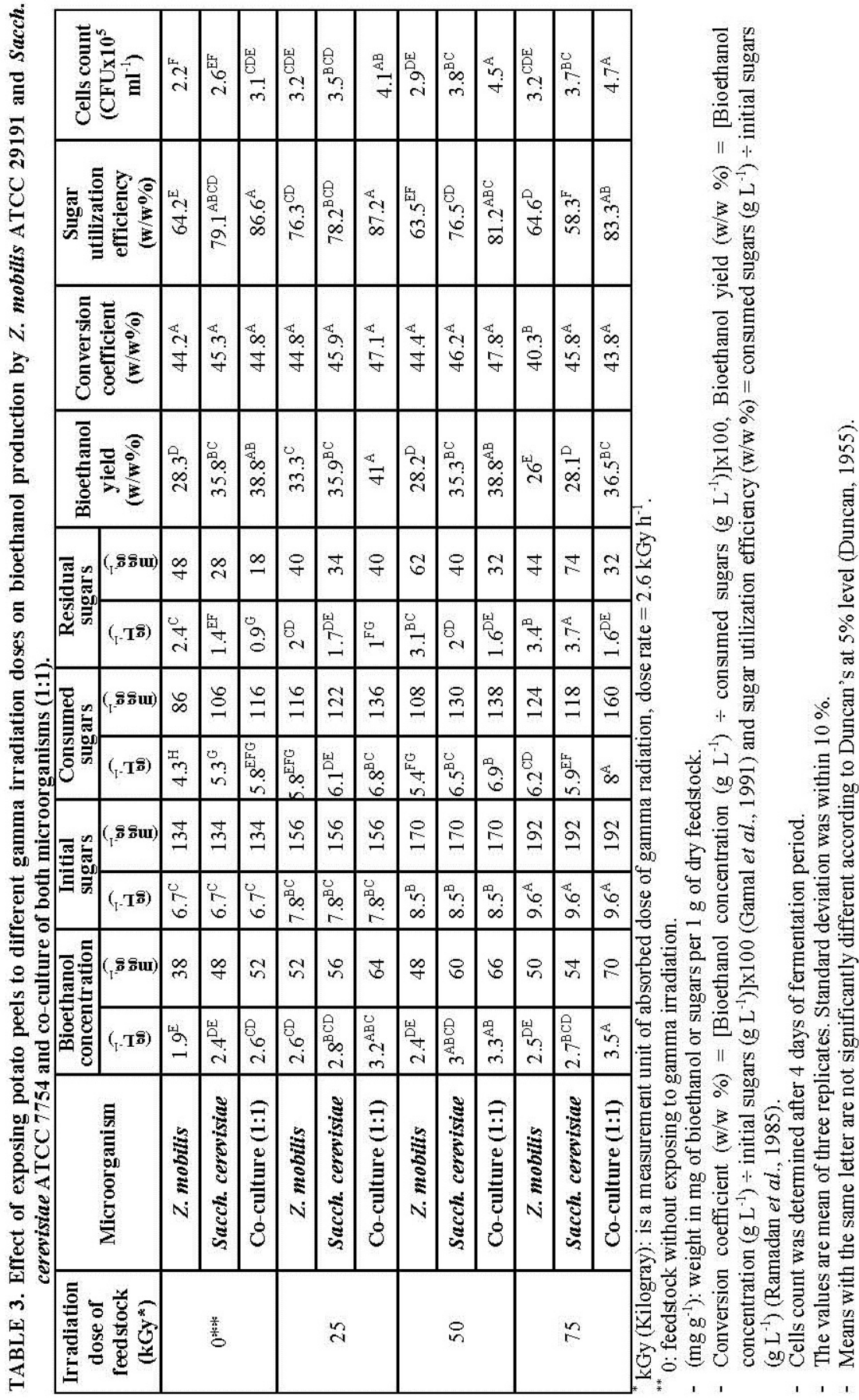


MICROBIAL PRODUCTION OF BIOETHANOL ...

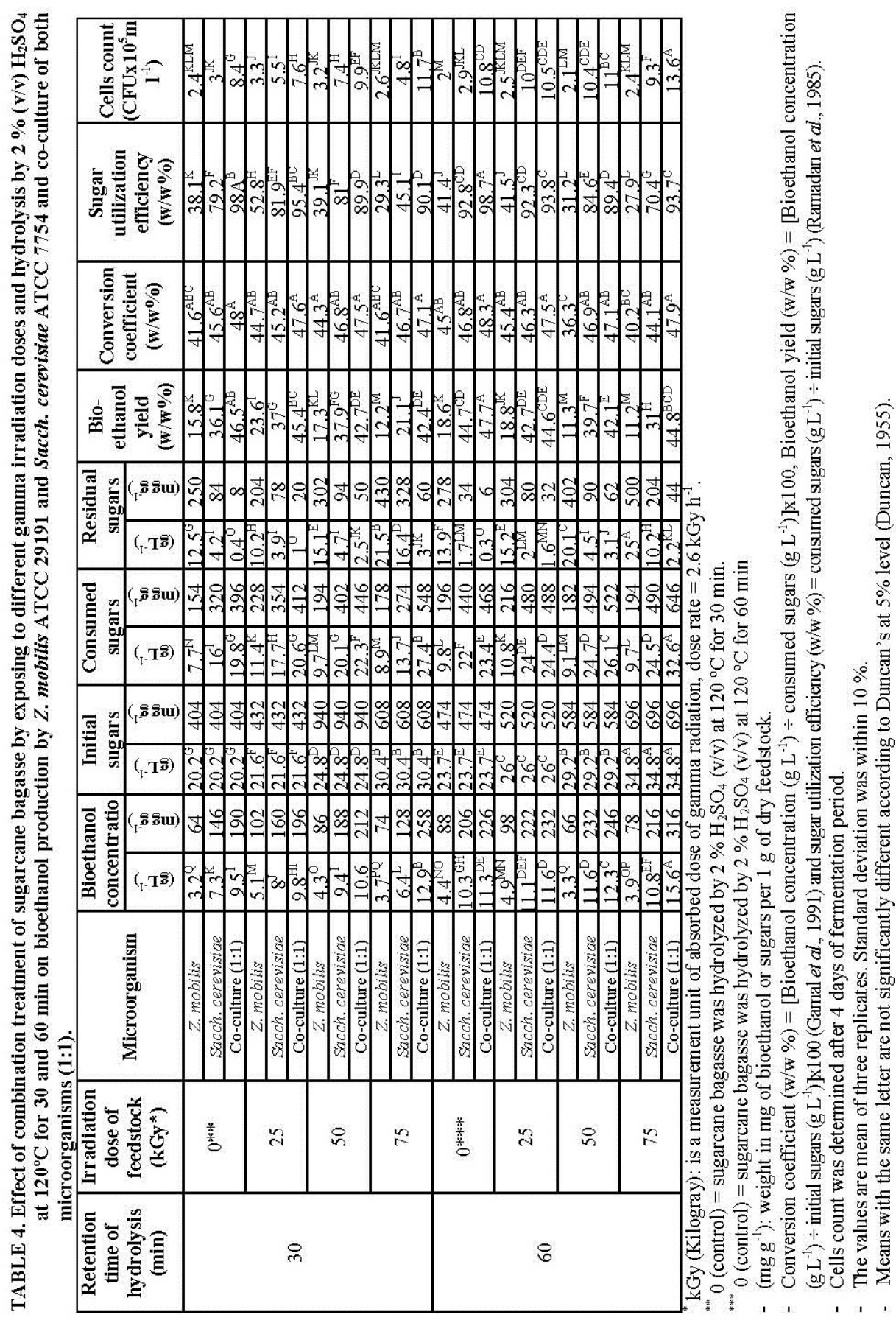




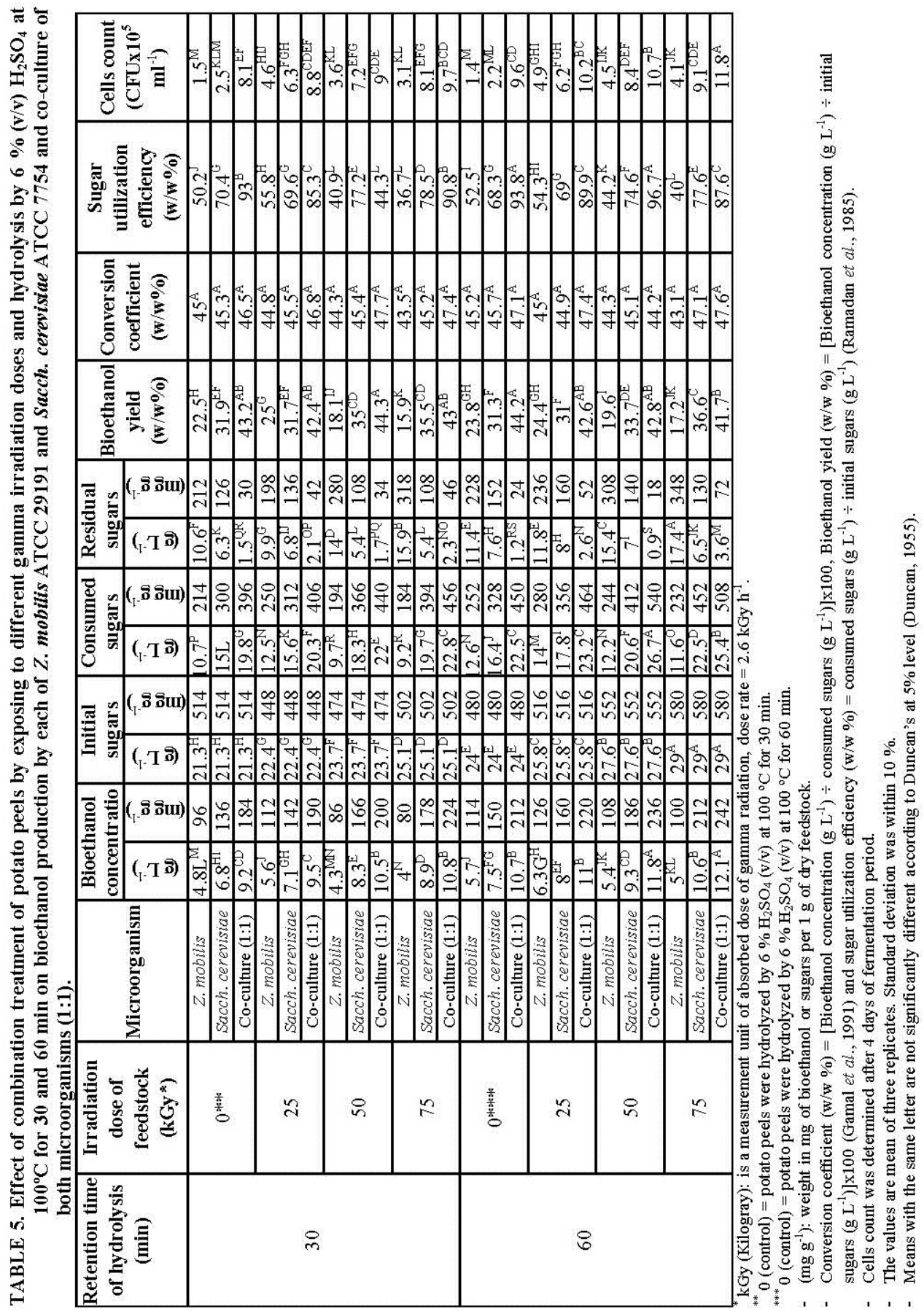




\section{References}

Abo-State, A. Ragab Mervat, A.M., El-Gendy, N.Sh., Farahat, Laila A. and Madian Hekmat R. (2013) Effect of different pretreatments on Egyptian sugarcane bagasse saccharification and bioethanol production. Egypt. J. Petrol. 22, 161-167.

Arapoglou, D., Varzakas, T., Vlyssides, A. and Israilides, C. (2010) Ethanol production from potato peel waste (PPW). Waste Management, 30, 1898-1902

Cardona, C.A., Quintero, J.A. and Paz, I.C. (2010) Production of bioethanol from sugarcane bagasse: Status and perspectives. Bioresour. Technol. 101, 4754-4766.

Crowell, E.A. and Ough, C.S. (1979) A Modified procedure for alcohol determination by dichromate oxidation. Am. J. Enol. Viticult. 30, 61-63.

Davis, Linda, Rogers, P., Pearce, J. and Peiris, P. (2006) Evaluation of zymomonasbased ethanol production from a hydrolysed waste starch stream. Biomass Bioenergy, 30, 809-814.

Duarte, C.L., Cardoso, V.M., Nagatomi, H.R., Oikawa, H., Mori, M.N. and Finguerut, J. (2008) Preliminary studies of cellulose from sugarcane bagasse hydrolysis using electron beam accelerator. In: IAEA Ed. Int. Symp. Util. Accel. 1, 1-10.

Duarte, C.L., Ribeiro, M.A., Oikawa, H., Mori, M.N., Napolitano, C.M. and Galvão, C.A. (2012) Electron beam combined with hydrothermal treatment for enhancing the enzymatic convertibility of sugarcane bagasse. Radiat. Phys. Chem. 81, 1008-1011.

Duarte, C.L., Ribeiro, M.A., Oikawa, H. and Mori, M.N. (2013) Study of thermal treatment combined with radiation on the decomposition of polysaccharides in sugarcane bagasse. Radiat. Phys. Chem. 84, 191-195.

Dubois, M., Gilles, K.A., Hamilton, J.K., Rebers, P.A. and Smith, F. (1956) Colorimetric method for determination of sugars and related substances. Anal. Chem. 28, 350-356.

Duncan, D.B. (1955) Multiple Ranges and Multiple F Test. Biometr. 11, 1-42.

Ferdian, W., Cheng, C., Kao, W., Lee, D.B. and Chang, J. (2012) Cellulosic ethanol production performance with SSF and SHF processes using immobilized Zymomonas mobilis. Appl. Energy, 100, 19-26.

Gamal, Rawia F., Nassar, Fatma R., Abd El-Hady, Hemmat M. and El-Sawy, M. (1991) Glycerol production by osmotolerant yeast strain using fermentor as fed batch and continuous culture techniques. Annals of Agriculture Science, Ain Shams University, Cairo, Egypt, 36, 319-421.

George, J., Carlos, M., Isaias, B., Souto Maria, A., Henrique, M. and Cesar, A. (2011) Dilute mixed-acid pretreatment of sugarcane bagasse for ethanol production. Biomass Bioenergy, 35, 663-670.

Hashem, M. and Darwish, Soumia M.I. (2010) Production of bioethanol and associated by-products from potato starch residue stream by Saccharomyces cerevisiae. Biomass Bioenergy, 34, 953-959. 
Oyeleke, S.B., Dauda, B.N., Oyewole, O.A., Okoliegbe, I.N. and Ojebode, T. (2012) Production of bioethanol from cassava and sweet potato peels. Adv. Environ. Biol. 6, 241-245.

Pak, S.C. and Simon, M.L. (2004) A method for routine measurements of total sugar and starch content in woody plant tissues. Tree Physiol. 24, 1129-1136.

Pattana, L.; Thani, A., Leelavatcharamas, V. and Laopaiboon, L. (2010) Acid hydrolysis of sugarcane bagasse for lactic acid production. Bioresour. Technol. 101, 1036-1043.

Qian, M., Tian, S., Li, X., Zhang, J., Pan, Y. and Yang, X. (2006) Ethanol production from dilute-acid softwood hydrolysate by co-culture. Appl. Biochem. Biotechnol. 134, 273-283.

Ramadan, E.M., El-Sawy, M. Gamal, Rawia F. and Abd El-Hady, Hemmat M. (1985) Growth parameters of yeast grown on agricultural residues using shake flask as a batch culture. Annals of Agriculture Science, Ain Shams University, Cairo, Egypt. 30, 25-45.

Ribeiro, M.A., Oikawa, H., Mori, M.N., Napolitano, C.M. and Duarte, C.L. (2013) Degradation mechanism of polysaccharides on irradiated sugarcane bagasse. Radiat. Phys. Chem. 84, 115-118.

SAS (1996) "Statistical Analysis System", SAS User's Guide: Statistics. SAS Institute. Inc. Editors, Cary, NC.

Stuart, N.W. (1936) Adaptation of The Micro-Kjeldahl Method for the determination of nitrogen in plant tissues. Plant Physiol. 11, 173-179.

Swings, J. and Deley, J. (1977) The biology of Zymomonas. Bacteriol. Rev. 41, 1-46.

Talyour, J. (1962) The estimation of numbers of bacteria by tenfold dilution series. $J$. Appl. Bacteriol. 25, 54-56.

Tiessen, H. and Moir, J.O. (1993) Total and organic carbon. In: "Soil Sampling and Methods of Analysis", M.E. Carter (Ed). . pp. 187-211. Lewis Publishers, Ann Arbor, MI

Thornley, M.J. (1963) Radition resistance among bacteria j. Appl. Bacteriol, 26, 334 345 .

Wang, K., Xiong, X., Chen, J., Chen, L., Su, X. and Liu, Y. (2012) Comparison of gamma irradiation and steam explosion pretreatment for ethanol production from agricultural residues. Biomass Bioenergy, 46, 301-308.

Wickerham, L.J. (1946) A critical evaluation of the nitrogen assimilation tests commonly used in the classification of yeasts. J. Bacteriol. 52, 293-301. 


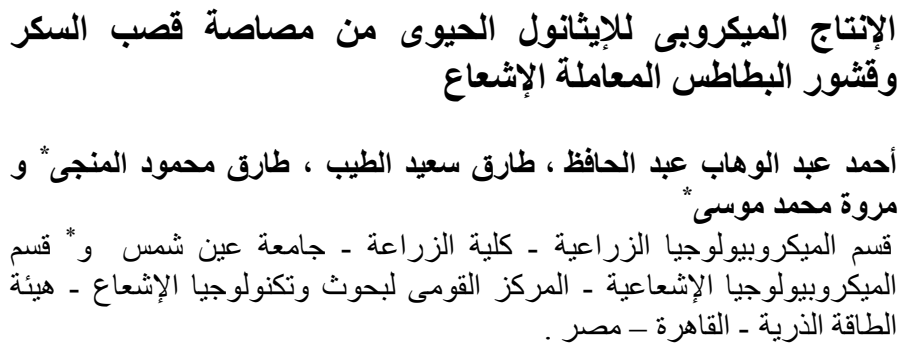

في الآونة الأخيرة ومع تفاقم أزمة الوقود غير المتجدد في جميع أنحاء العالم وما

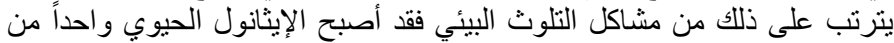

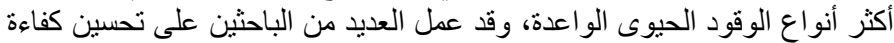

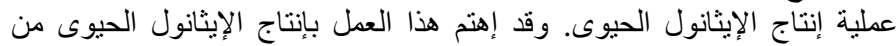

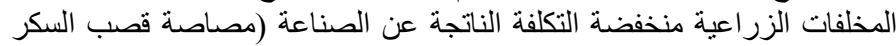

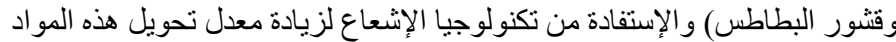

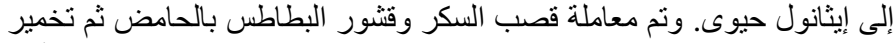
ناتج التحلل إما عن طريق Saccharomyces cerevisiae ATCC 7754

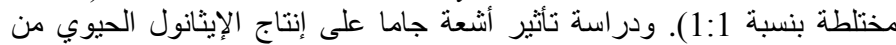

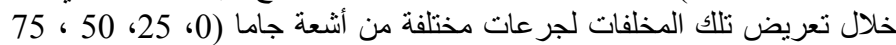

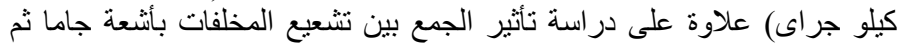

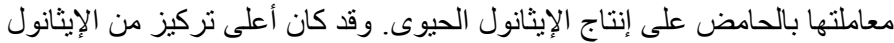

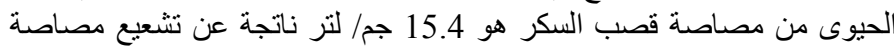

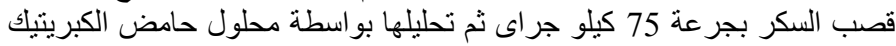

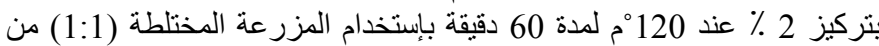
ن. mobilis ATCC 29191 ، Sacch. cerevisiae ATCC 7754 ناحية أخرى كان أعلى تركيز من الإيثانول الحيوى من قشور البطاطس هو 12.1

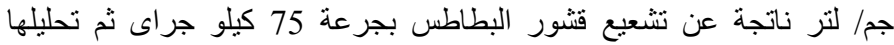
بو اسطة محلول حامض الكبريتيك بتركيز 6 \% عند 100 10 م لمدة 60 دقيقة بإستخدام

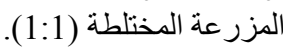

